\title{
Filozofia życia Meraba Mamardaszwilego i jej znaczenie dla psychologii
}

Egzystencja jest właściwie tym, co człowiek powinien urzeczywistnić „tu i teraz”. Nie należy zamiaru tego odkładać na jutro bądź przenosić na barki innych ludzi, sąsiedniego narodu, państwa czy społeczeństwa. Musisz tego dokonać samodzielnie. Człowiek nie jest jednak do tego skłonny.

Merab Mamardašvili, Lekcii o Pruste (psihologičeskaâ topologiâ puti)

Merab Konstantinowicz Mamardaszwili (1930-1990) jest filozofem, którego myśl ma dla psychologii szczególne znaczenie. Utrzymywał życzliwe kontakty z psychologami oraz miał duży wpływ na ich życie prywatne. Liczne grono psychologów częściej przysłuchiwało się jego poglądom niż koledzy filozofowie. Nigdy się z nim nie spotkałem i nie kontaktowałem, słyszałem [gdzieniegdzie] jego nazwisko, ponieważ chodził sąsiednimi korytarzami. Gdy umarł, byłem trzydziestoletnim doktorem, być może dlatego nie do końca rozumiałem, jak ważną był postacią. Zapoznałem się z jego myślą filozoficzną pięć bądź siedem lat po jego śmierci, zapewne na podobnej zasadzie,

* Przekład za zgodą autora na podstawie: Dmitry Leontiev, „Filosofiâ žizni M. Mamardašvili i ee značenie dlâ psihologii”, Kul'turno-istoričeskaâ psihologiâ, no 1, (2011): 2-12. 
na jakiej on nawiązywał do Kartezjusza i Kanta, a Viktor Frankl odwoływał się do Maxa Schelera. I choć nie spotkali się, nie przeszkodziło to jednak Schelerowi wywrzeć kolosalnego wpływu na Frankla.

Celem niniejszego artykułu jest przedstawienie filozoficznej koncepcji życia, rozwiniętej przez Mamardaszwilego w dwóch wykładach wygłoszonych w roku 1982 i na przełomie lat 1984 i 1985 w Tbilisi, a następnie opublikowanych w formie monografii zatytułowanych kolejno „Wykłady o Prouście” i „Psychologiczna topologia drogi”' Z formalnej perspektywy oba kursy poświęcone są jednej kwestii, są podobne, ale nie powielają istotnych problemów. Drugi kurs jest nieco bardziej rozwinięty i ustrukturyzowany. Podejmę próbę systematyzacji podstaw filozoficzno-psychologicznych w celu zrozumienia refleksji Mamardaszwilego o ludzkim życiu, a następnie zestawię z egzystencjalną tradycją w psychologii.

Niezwykle trudne jest dyskutowanie o tekstach i ideach Mamardaszwilego. Niemożliwe wydaje się streszczenie głoszonych przez niego poglądów jako zbioru określonych norm, ponieważ jego światopogląd nie pasuje do naturalnego filozoficznego i psychologicznego języka. Prezentowane przez Mamardaszwilego wykłady obrazowały proces językowego rozwoju, dlatego nie można znaleźć w nich wyraźnych analogii do rygorystycznych definicji. Dotyczy to w największym stopniu dwóch wspomnianych wykładów o Prouście. Przedstawiono w nich cykliczny ruch myśli, ponieważ Mamardaszwili stale powraca do tych samych rzeczy, lecz stara się wyjaśnić je nieco inaczej, używając odmiennych słów, bo wyrażeń dokładnie oddających to, co pragnie przekazać, nie znajdziemy ani pośród leksyki filozoficznej, ani w słownictwie potocznym. W związku z powyższym przypomina mi się jedna z licznych historii krążących o Mamardaszwilim. Gdy na początku wykładów o Prouście jeden z oburzonych słuchaczy zapytał, dlaczego wykładowca Gruzin czyta w języku rosyjskim w Tbilisi wykłady gruzińskim słuchaczom, Mamardaszwili odpowiedział: Proust nie jest przekładalny na język rosyjski. Muszę jednak stwierdzić, że rosyjski, francuski i inne języki są również dalekie od tego, aby precyzyjnie przedstawić myśli filozofa. Nie przez przypadek w innych swoich wykładach uprzedzał, że powinniśmy odbierać idee wielkich

${ }^{1}$ Merab Mamardašvili, Lekcii o Pruste (psihologičeskaâ topologiâ puti), (Moskva: Ad Marginem, 1995), 5. 
filozofów literalnie, bo nie zawsze starcza im słów, aby wyrazić swoje myśli i to, co głoszą w sposób metaforyczny. Nie ma wątpliwości, że kwestia ta odnosi się do samego Mamardaszwilego. Kolejna anegdota brzmi następująco: w przerwie pomiędzy wykładami podszedł do Mamardaszwilego słuchacz i przyznał się, że nie wszystko zrozumiał z jego wykładu. „Nie było to moim celem" - odpowiedział spokojnie Gruzin.

Myślenie Mamardaszwilego nie wpasowuje się w strukturalny podział filozofii i nie uznaje granic pomiędzy filozofią a innymi dyscyplinami humanistycznymi. „Nie istnieje żadna osobna etyka, osobna estetyka, osobna logika, osobne uczucia itd."2 Podjęta przez niego argumentacja wyraża się w sądach o naturze ludzkiej, w funkcjach literatury i sztuki, w fenomenologicznej analizie bezpośredniego doświadczenia, w ontologicznych twierdzeniach, w historyczno-socjologicznej analizie homo soveticus, w fenomenologii miłosnych przeżyć. Pełny i systematyczny zarys poglądów Mamardaszwilego jest nie tyle niemożliwy, ile nawet nie jest konieczny. Według niego rozumienie pojawia się nie wraz z przyrostem informacji, lecz w wyniku oglądu znanej rzeczywistości, przez pryzmat innej struktury, innej perspektywy świadomości. Pozwala nam zrozumieć, co mogło być już zrozumiane dawno temu, lecz z jakiegoś powodu tak się nie stało. Moim zdaniem teksty Mamardaszwilego stanowią właśnie takie struktury, które pomagają wniknąć w sens problemów $\mathrm{z}$ innej strony. One były i są przedmiotem moich zainteresowań, a w szczególności problematyka ludzkiego życia. Nieprzypadkowa wydaje się charakterystyka jego nauki jako egzystencjalnej soteriologii, „filozofii osobistego zbawienia” $\mathrm{i}$ jako „fenomenologii miłości, życia i śmierci”.

Właśnie przez pryzmat wspomnianych kwestii interpretuję rozległy świat Mamardaszwilego, ale oczywiste jest, że inni ludzie odbiorą tę rzeczywistość w odmienny sposób. Prezentuję treść tego artykułu nie tylko ze względu na znaczenie idei Mamardaszwilego. Osobisty sens tego wywodu jest ważny w odniesieniu do całości mojego życia (nie tylko zawodowego). Sam Ma-

\footnotetext{
2 Mamardašvili, Psihologičeskaâ topologiâ puti (Moskva: Izdatel'stvo Russkogo Hristianskogo gumanitarnogo instituta, 1997), 340.

${ }^{3}$ Ėrih Ûrevič Solov'ev, „Èkzistencial'naâ soteriologiâ Meraba Mamardašvili” in: Merab Konstantinovič Mamardašvili, ed. Nélli Vasíl'evna Motrošílova (Moskva: ROSSPÈN, 2009).

${ }^{4}$ Nélli Vasíl'evna Motrošílova, Merab Mamardašvili: filosofskie razmyšleniâ i ličnostnyj opyt (Moskva: Progress-Tradiciâ, 2007), 316.
} 
mardaszwili znajdował się w analogicznej sytuacji do Prousta, a w jego literackich tekstach dostrzegał głęboką myśl filozoficzną, określając ją „filozofią okrucieństwa"s. Starał się odkryć sens tkwiący w prozie Prousta z punktu widzenia własnego doświadczenia. Również ja próbuję odkryć pewną filozofię sensu Mamardaszwilego w nadziei, że czytelnicy będą kontynuować ten proces. Stoją przede mną nie tylko hermeneutyczne czy analityczne zadania, a treść tego artykułu jest podsumowaniem mojej interpretacji, mojego częściowego rozumienia myśli Mamardaszwilego ${ }^{6}$.

$\mathrm{Z}$ etymologicznego punktu widzenia rosyjskie słowo ponât', jak również angielskie conceive i francuskie comprendre oznaczają "przyjąć w siebie” i związane są z semantyką zapłodnienia i poczęcia. Spotkanie z „topologią psychologiczną" Mamardaszwilego wciąż ma potężny, wzbogacający wpływ nie tylko na moją pracę naukową, ale na rozumienie życia i egzystencjalnej ścieżki. Oczywiste jest, że nie da się usunąć subiektywnej opinii interpretatora, dlatego w celu pewnego jej zrównoważenia [w artykule] znajduje się sporo cytowań. Wyrwane z kontekstu cytaty, przy całej dokładności tego zabiegu, nie mogą zastąpić pierwowzoru.

\section{Mamardaszwili, psychologia i egzystencjalizm}

Pod wieloma względami poglądy późnego Mamardaszwilego są bliskie tradycji egzystencjalno-fenomenologicznej. Podobieństwo jest mniej lub bardziej powszechnie akceptowane, dostrzegalne jest zaś już w samych stylistycznych cechach dyskursu. Rozważania Mamardaszwilego są z jednej strony dość płynne i nie mogą zostać zamknięte w ścisłych kategoriach, sprzeciwiając się tym samym wpisaniu w strukturę, z drugiej zaś nader ra-

\footnotetext{
${ }^{5}$ Mamardašvili, Psihologičeskaâ topologiâ puti, 36.

${ }^{6}$ Właśnie dlatego niektórzy badacze twórczości Mamardaszwilego zaobserwowali nieścisłość i nieautentyczność rozszyfrowanych stenogramów jego wykładów, stanowiących podstawę cytowanych tu wydań, lecz nie są one dla mnie zasadnicze. U samego Mamardaszwilego, jak zauważa Motrošilova, „nie znajdziemy zbyt wielkiego poszanowania dla historycznych i filozoficznych szczegółów”. Są one ważne w innym kontekście. W odniesieniu do realizacji celów niniejszego artykułu takie elementy nie odgrywają jednak zbyt dużej roli, więc warianty tekstowe mogą zostać pominięte.
} 
dykalne, sztywne i jednoznaczne. Jedno z jego ulubionych powiedzeń brzmi: „Diabeł gra nami wtedy, gdy nie myślimy dokładnie”. Dlatego Mamardaszwili poruszał się po głęboko indywidualnej trajektorii.

„Po pierwsze, określa on kwestie fenomenologiczne, dodając im wyraźnie egzystencjalno-ontologicznej, osobowej treści, a po drugie, w sposób świadomy stara się odróżnić swą fenomenologię egzystencjalną od innych jej typów". Sołowjow ${ }^{9}$ odnotowuje również obie idee Mamardaszwilego, które są zgodne z tradycją egzystencjalną, a jednocześnie są od niej różne. Nigdy nie rozdzielał on świadomości i bycia-w-świecie, opierając się i na aktywnym, i refleksyjnym człowieku, ani też nie próbował opisać tego bycia w sposób analityczny, jak dokonali tego czołowi przedstawiciele filozofii egzystencji (Heidegger, Jaspers, Sartre i inni). W jego „psychologicznej topologii drogi” wyrażenie „topologia drogi” wskazuje na procesy egzystencjalne, ontologię fundamentalną, a „psychologiczna” - na procesy zachodzące w świadomości człowieka, towarzyszące jego podążaniu tą drogą (bądź z dala od niej). Mamardaszwili mówił o swoich poglądach, definiując je mianem „psychologii autentycznej”. Często referował je psychologom, z częścią z nich wiązały go relacje przyjacielskie i „wspólne sprawy”, lecz jego stosunek do psychologii akademickiej był bardzo krytyczny:

To, co dzisiaj nazywa się nauką psychologiczną, dla nas generalnie nie ma żadnego znaczenia. Bada ona nie tyle człowieka laboratoryjnego, ile pewne laboratoryjne pojęcie o człowieku. Podstawowe rzeczy, w zależności od których powstaje bądź nie powstaje, udaje się bądź nie udaje nasze życie wewnętrzne, w ogóle nie występują w teorii psychologicznej. Przykładowo można stwierdzić, że pewien sposób myślenia o śmierci i postawa wobec niej ma decydujące znaczenie dla ukształtowania nas jako istot ludzkich i psychologicznych. Albo relacja, nadzieja i wiara są jednoznacznie najważniejsze w naszym życiu. Tymczasem takie zjawisko jak osobowość (przy czym właśnie zjawisko, a nie słowo, gdyż słowo to znamy) określa strukturę, konkretny sposób bycia. Osobowości tej w ogóle nie odnajdziemy w psychologii, chociaż ma ona istotne znaczenie

\footnotetext{
7 Tamże, 207. Mamardašvili, Soznanie i civilizaciâ: Teksty i besedy (Moskva: Izdatel'stvo „Logos”, 2004), 154.

${ }^{8}$ Nélli Vasíl'evna Motrošílova, Merab Mamardašvili: filosofskie razmyšleniâ i ličnostnyj opyt, 154.

9 Ėrih Ûr'evič Solov'ev, Èkzistencial’naâ soteriologiâ Meraba Mamardašvili.
} 
dla samego sposobu przepływu i urzeczywistnienia naszych podstawowych skłonności, możliwości, zdolności i talentów ${ }^{10}$.

Prawdopodobnie zdanie Mamardaszwiliego o człowieku jest bliższe psychologii egzystencji niż filozofii egzystencji. Psychologia egzystencji powstała w latach 1930-1960 pod wpływem filozofii egzystencji Kierkegaarda, Heideggera, Sartre’a i Jaspersa oraz w nie mniejszym stopniu antropologii filozoficznej Schelera, Bubera i Tillicha, a także psychologii klinicznej i psychiatrii pierwszej połowy XX stulecia. Za „ojca” psychologii egzystencji uchodzi bliski przyjaciel Freuda, szwajcarski psychiatra Ludwig Binswanger, bardziej szczegółowe teorie filozoficzne zaś zostały zaproponowane w latach 1950-1960 przez Frankla, Lainga, Maya i Bugentala. Autorzy ci sugerowali, że w dużym stopniu poglądy na bycie-w-świecie człowieka nakładają się na siebie. Łączą one stanowiska psychologiczne i filozoficzne wychodzące poza filozofię egzystencjalizmu XIX i pierwszej połowy XX wieku. Można doszukać się wielu podobieństw między psychologią Mamardaszwilego a psychologią egzystencji Maya i Bugentala. Zarówno w jednej, jak i w drugiej mamy do czynienia z refleksyjnym wymiarem życia człowieka, opierającego się jedynie na swoich przeżyciach, w niepewnych (niesprzyjających) warunkach.

Nie jest moim celem skupianie się na charakterystyce tradycji egzystencjalnej w naukach o człowieku ${ }^{11}$. Zadaniem tego artykułu nie jest uzasadnianie bliskości myśli Mamardaszwilego w stosunku do tej tradycji, lecz oddzielenie jego unikatowego podejścia, wpisującego się w tę tradycję i wychodzącego poza nią. Psychologiczną topologię drogi można określić mianem antropologii postegzystencjalnej, scalającej tradycję egzystencjalną, a przy tym posuwającą się jeszcze dalej w rozumieniu miejsca człowieka w świecie.

${ }^{10}$ Mamardašvili, Lekcii o Pruste, 126-127.

${ }^{11}$ Tamże, 127. 


\section{Dwa aspekty życia}

W centrum rozważań Mamardaszwilego, przedstawionych w Wykładach o Prouście, usytuowane jest pojęcie życia. Stwierdza on, że „życie to jedyne, z czego zdajemy sobie sprawę, dostając i dzieląc to, czego pragniemy, i jest jedyną rzeczą, do której podążamy, nawet jeśli pozostajemy żywi”. Jednak Mamardaszwili życie to nazywa „innym życiem”, różnym od tego, które ujawnia się w codziennej rutynie. W innym miejscu podkreśla, że „u podstaw wszystkich wielkich filozofii i religii leży jedna myśl: rzeczywiście istnieje jakieś inne życie, bardziej rzeczywiste niż nasze, jest coś jeszcze, co również żyje inaczej niż my, bardziej sensownie; ta wyższa forma życia, to sacrum, świętość, czy "życie w innym czasie, w innym miejscu« itd.". Myśliciel mówi o dwóch „trybach” lub „rejestracjach” życia, co odzwierciedla fundamentalną dwoistość naszej egzystencji. Tryb pierwszy jest egzystencją codzienną i powierzchowną, kierowaną nawykami i stereotypami. Bieg czasu nie rodzi wydarzeń, a życie samo w sobie nie jest całkowicie rzeczywiste, jest mrokiem, mgłą, co na Dalekim Wschodzie określa się jako Maja. Drugi tryb życia ma charakter niepewny, chaotyczny; Mamardaszwili nazywa to „życiem świadomym". Na tym poziomie ma ono swoje prawa, a my od czasu do czasu możemy za pomocą świadomych wysiłków uzyskać do niego dostęp. „Zawsze jesteśmy istotami dwoistymi: dojrzewającymi w połowie do rzeczywistego, świadomego życia, a w połowie do wiedzy, że świadome życie od nas ucieka”12. Mamardaszwili wskazuje na przebłyski „możliwości innego życia”, z którymi zderzają się w pewnych punktach bohaterowie powieści Prousta ${ }^{13}$. "Inne życie” jest poukładane w sensie istnienia nieubłaganych praw, które mamy szansę poznać, $\mathrm{w}$ przeciwnym razie będziemy skutecznie ukrywać przed swoim wzrokiem prawdziwe życie i całkowicie rozpuścimy się w płytkiej egzystencji, w trybie „rozpraszania i rozkładu” ${ }^{14}$.

Dwa omówione tryby życia różnią się między sobą w wielu istotnych aspektach. „Jednym z trybów jest ten, w którym funkcjonuje stale narastająca

\footnotetext{
${ }^{12}$ Tamże, 447.

${ }^{13}$ Mamardašvili, Psihologičeskaâ topologiâ puti, 50.

${ }^{14}$ Tamże, 51.
} 
żywa edukacja jako sposób życia, powodując w nas realne odczucia. Inny, rzeczywisty tryb doprowadza do sytuacji, że nie jesteśmy w stanie zawsze trwać w naszych autentycznych nastrojach, gdyż są one rozproszone"15. Mamardaszwili porównuje powierzchowny tryb egzystencji do śmierci.

„Życie stanowi możliwość bycia innym (w odróżnieniu od tego, co można oczekiwać lub czego pożądać). To dzięki niej można napisać inną książkę bądź wymyślić inną myśl - na własnych autonomicznych podstawach"16. Jednak w każdym momencie życie splata się ze śmiercią. „Śmierć nie następuje po życiu, albowiem już w nim uczestniczy. W naszym życiu duchowym zawsze znajdziemy martwe produkty życia codziennego. Człowiek często zderza się z tym, że te martwe odpady zajmują całe życie, nie pozostawiając w nim miejsca dla żywego uczucia, dla żywej myśli, dla autentycznego życia" ${ }^{17}$. Martwy oznacza, że nie masz do czynienia $z$ autentycznym i prawdziwym uczuciem, a jedynie z reprodukcją, nie doświadczasz bowiem niczego samodzielnie.

Każdy żywy stan ma swojego martwego sobowtóra i nie zawsze łatwe jest uchwycenie różnicy pomiędzy nimi, gdyż nie wszyscy, którzy wydają się żywi, są tacy w rzeczywistości. Kolejną różnicą jest fakt, że żywy organizm odtwarza warunki swojego istnienia, stwarza coś do niego podobnego. „Czym tak naprawdę "żywe« wyróżnia się na tle wszystkiego innego? Wyróżnia się zwłaszcza zachowaniem indywidualności, której nie można ani napisać, ani wymyślić i która ujawnia się jako bycie lub nie-bycie, ale także stwarza podobne"18. Życie, w tym życie wieczne, może powstać jedynie od żywego. Nie ma ono początku samo w sobie, nie pochodzi od martwego, by następnie stać się żywym ${ }^{19}$. „Jedyną wartością, której szukamy we wszystkich przejawach samego siebie i otoczenia, jest życie (żywotność)”20. Psychologia rzeczywistości ludzkiej powstaje jako próba stałego ożywiania tego, co martwe. „Ożywiamy martwe słowa, ożywiamy martwe gesty, martwe konwencje”21.

\footnotetext{
${ }^{15}$ Mamardašvili, Lekcii o Pruste, s. 310.

16 Tamże, 128-204. Mamardašvili, Opyt fizičeskoj metafiziki (Vil’nûsskie lekcii po social’noj filosofii) (Moskva: Progress-Tradiciâ, 2009), 58.

17 Mamardašvili, Psihologičeskaâ topologiâ puti, 7.

${ }^{18}$ Mamardašvili, Lekcii o Pruste, 232.

19 Tamże, 339.

20 Tamże, 128.

${ }^{21}$ Tamże.
} 
Jednocześnie „istnieją takie powiązania i ograniczenia, które mogą istnieć bez względu na nas (prawda, z naszym udziałem) i uśmiercać to, co powinno być żywe" 22 . Prawie 99\% naszej codziennej egzystencji składa się z martwych

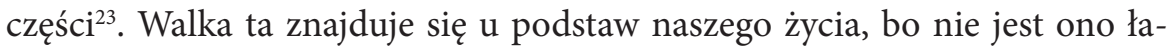
twe, wymaga od człowieka stałego wysiłku, wewnętrznej pracy dokonywanej przez każdego, kto żyje. „Żyją, oczywiście, nie wszyscy...” - podkreśla Mamardaszwili ${ }^{24}$. Jego poglądy na żywe i martwe elementy naszej egzystencji są zdumiewająco bliskie ideom rozwijanym w tym samym czasie przez wybitnego psychoterapeutę zajmującego się psychologią egzystencji Jamesa Bugentala. Kilka lat temu czasopismo „New Yorker” opublikowało karykaturę przedstawiającą młodą rodzinę, ojca, matkę i małego chłopca. Gdy spokojnie spacerowali ulicą, chłopiec zapytał: „Żyjemy w świecie czy w filmie?”. $\mathrm{Z}$ ust dzieci często płyną najbardziej fundamentalne pytania egzystencjalne! Większość ludzkiej egzystencji upodabnia się do filmu. Nie rozumiemy życia, wykonujemy zaprogramowane działania, doświadczamy zestawu emocji i działamy na mocy rozstrzygniętych już sądów.

O obecności $\mathrm{w}$ filmie mówimy nie dlatego, że jesteśmy bezradnymi ofiarami naszych nawyków, naszego środowiska, naszych hormonów i naszego dziedzictwa, lecz dlatego, że straciliśmy wnętrze ${ }^{25}$. „Życie to fundamentalne zajęcie, jednak działamy tylko częściowo. Możliwe wydaje się jednak, że można być żywym w różnym stopniu, nie jest to zależne od odpowiedzi »tak lub nie "26. Mamardaszwili stosuje inną metaforę do opisu dwóch sposobów życia: sen i czuwanie. „To, co nazywamy rzeczywistością, najczęściej składa się z takich przedstawień, z takich obrazów i stanów, które pozwalają nam spać dalej. W tym przypadku słowo »spać« oznacza nie znać i nie dostrzegać rzeczywistości. W tym sensie rzeczywistość ma strukturę snu”27. W przeciwieństwie do świata snów autentyczny świat generuje wydarzenia z naszego

\footnotetext{
22 Tamże.

${ }^{23}$ Tamże, 466.

${ }^{24}$ Mamardašvili, Psihologičeskaâ topologiâ puti, 61.

${ }^{25}$ James Bugental, “Outcomes of an Existential Humanistic Psychotherapy: A Tribute to Rollo May”, The Humanistic Psychologist, vol. 19, 1 (1991): 3.

${ }^{26}$ James Bugental, "Lessons Clients Teach Therapists", Journal of Humanistic Psychology, vol. 31, 3, (1991): 30.

${ }^{27}$ Mamardašvili, Psihologičeskaâ topologiâ puti, 32.
} 
życia wewnętrznego. „Mówiąc »świat rzeczywisty«, mam na myśli ten świat, który wywołuje wydarzenia. Są to wydarzenia naszej duszy, ekscytacja, pamięć" 28 .

W innym miejscu Mamardaszwili zaznaczył, że zwyczajny, powierzchowny, „normalny” rejestr życia w istocie staje się patologią ${ }^{29}$. Ten „tryb zapomnienia, rozproszonej uwagi, lenistwa i strachu jest oderwany, odłożony na jutro" ${ }^{30}$. Jesteśmy zazwyczaj ślepi i głusi na prawdziwą strukturę naszego życia, na życie w ogóle. Tylko w trakcie niektórych uprzywilejowanych chwil, $\mathrm{w}$ obliczu doświadczeń zawierających potencjalne zrozumienie, czujemy „szelest tkanin” z prawdziwego życia. Daje nam to szansę, aby zatrzymać się i uruchomić ruchy w obrębie tego doświadczenia i wydobyć z niego sens ${ }^{31}$. Wrażenia przychodzą same, nie mogą być powodowane dowolnie. Jest to zjawisko, poprzez które świat objawia nam prawdę. W naszej duchowej aparaturze istnieje jednak wiele mechanizmów, które służą podtrzymaniu nas w śpiącym stanie, nie pozwalając zobaczyć tego, czym tak naprawdę świat jest, bądź też "go objaśniają" ${ }^{2}$. Mechanizmy te można rozumieć jako rodzaj obrony psychologicznej. Mamardaszwili opisuje jednak o wiele bardziej złożone zjawiska, takie jak: lenistwo, strach i nadzieję - nadzieję, że coś się zmieni i nie będziemy musieli zmieniać się sami ${ }^{33}$. Człowiek jest przecież fantastycznym stworzeniem zacofania i upartej chytrości. Jest gotowy na wszystko, byle nie pozostać $w$ ruchu i nie zanegować samego siebie ${ }^{34}$.

Świat ujawnia się tylko zaangażowanemu człowiekowi, temu, kto ma odwagę stanąć na skraju, na linii w nadziei, że stanie się coś, co przyniesie jasnośćc ${ }^{35}$. Przykładem jest związek z kobietą, według Prousta (i Mamardaszwilego) radykalnie różniący się od relacji z przyjacielem. Możesz sypiać z kobietą, co oznacza ryzyko postawienia wszystkiego na jedną kartę, lecz jest to dla człowieka konstruktywne ${ }^{36}$. Niczego nie można się dowiedzieć, jeśli

\footnotetext{
${ }^{28}$ Mamardašvili, Lekcii o Pruste, 446.

${ }^{29}$ Tamże, 208.

${ }^{30}$ Tamże, 310.

${ }^{31}$ Mamardašvili, Psihologičeskaâ topologiâ puti, 105, 134-135.

${ }^{32}$ Tamże, 30.

${ }^{33}$ Mamardašvili, Lekcii o Pruste, 21.

${ }^{34}$ Mamardašvili, Soznanie i civilizaciâ: Teksty i besedy, 162.

${ }^{35}$ Mamardašvili, Lekcii o Pruste, 14, 28.

${ }^{36}$ Tamże, 198-199. Mamardašvili, Psihologičeskâ̂ topologiâ puti, 179.
} 
nie jest się zaangażowanym (choć przez zaangażowanie zniekształca się poznanie) ${ }^{37}$. Zaangażowanie oznacza postawienie wszystkiego na „jedną kartę”, zainteresowanie się swoim przeznaczaniem ${ }^{38}$. Możliwy jest ruch - zgodnie z prawami prawdziwego życia - który Mamardaszwili nazywa „drogą”. Jest to „wyodrębnianie żywych cząstek z doświadczenia ludzkiego i ich gromadzenie" 39 .

\section{Przyczynowość, prawo i wysiłek}

Jeśli posuwamy się nieustannie po wyznaczonej drodze, nasze działania nie są determinowane dosłownie. Mamardaszwili obwinia główny nurt psychologii XX stulecia, starający się wyjaśnić obiektywnie zjawiska psychiczne, za nadmierne przywiązanie do wyjaśnień deterministycznych. Rzeczywiście, tego rodzaju wyjaśnienie, odpowiadające płytkiemu poziomowi życia, Mamardaszwili opisuje jako „śmierć” lub „sen”, w których zdarzenia, w tym duchowe, wywołane są przez pewne zdarzenia i mechanizmy (jak w przypadku „niewoli” w myśli Jamesa Bugentala). Przyczynowość odnosi się do tego, co w człowieku nie jest ludzkie. W obszarze zjawisk specyficznie ludzkich pojęcia deterministyczne mają niewielkie zastosowanie. „Gdy jestem głodny, rozrywam zębami (widelcem i nożem - bez różnicy) kawałek mięsa albo korzystając z własnej siły, wyrywam słabszemu; powtarzam, dopóki nie ma prawa, to wszystko jest epizodem $\mathrm{z}$ historii naturalnej. Przyczynowość człowieka nie istnieje, na tym polega istota człowieka: nie można w nim przyczynowo wywoływać człowieka"40.

Wiele z kluczowych postanowień Mamardaszwilego dotyczących „psychologicznej typologii” wywodzi się z następujących myśli Prousta: „W naszych życiowych warunkach, na tej ziemi nie ma żadnego powodu, żebyśmy czuli się zobowiązani do czynienia dobra, do bycia ludźmi delikatnymi czy zwyczajnie uprzejmymi [...] Wszystkie te obowiązki [...], które nie mają

\footnotetext{
37 Tamże, 130.

38 Tamże, 215.

39 Tamże, 395.

40 Tamże, 416.
} 
swoich roszczeń w obserwowanej rzeczywistości, wydają się należeć do innego świata, opartego na życzliwości, sumienności, poświęceniu, świat ten jest zupełnie inny od naszego" ${ }^{41}$. Mamardaszwili wielokrotnie powtarza, że dobro nie ma przyczyn. Stosujemy jednak przyczynowe wyjaśnienie zła (był rozgniewany, obrażony, ponieważ znajdował w stanie furii i wściekłości), ale w obliczu dobrych uczynków możemy odrzucić takie wyjaśnienia i mówić, że osoba działała „w dobrej wierze”, to znaczy bez przyczyny ${ }^{42}$. „Sumienie jest zjawiskiem, które jest przyczyną samego siebie i nie ma innych przyczyn chociażby dlatego, że w naszym języku używamy go wtedy, kiedy nie szukamy przyczyn. Słowo »sumienie« pojawia się wtedy, gdy nie wyszukujemy ani socjologicznych, ani psychologicznych, ani biograficznych wyjaśnień czynu. Wyrażenie to występuje wtedy, gdy zastępujemy cały ciąg przyczynowy. Sumienie jest więc elementem ciągu przyczynowego, niemającego samoistnej przyczyny” ${ }^{43}$. Mamardaszwili podkreśla w szczególności myśl Prousta o „innym świecie" jako źródle zjawisk, które nie są wytłumaczalne w odniesieniu do tego świata. Ten inny świat jest również źródłem praw, którym podlega nasze życie, oprócz świadomości. „Zdecydowałeś się żyć, więc postawiłeś samego siebie na jedną kartę, czyli zostałeś już rzucony w jakieś magnetyczne linie praw, po których będziesz przechodzićc4; jeśli nie uda ci się zauważyć tych praw, okażesz się ofiarą ${ }^{45}$. W naszym życiu zdarzają się przebłyski, świetnie opisane w powieści Prousta. Kiedy przez chwilę dostrzegamy przebłysk pioruna prawdziwego życia przenikający przez rutynę sennej egzystencji, może to nas doprowadzić do zrozumienia fundamentalnych praw. Jeśli tylko uda się nam złapać i utrzymać ten moment, a także podjąć wysiłek i zmusić swoją świadomość do pracy w celu zrozumienia sensu tego wybuchu, nie należy pozwolić mu odejść i rozproszyć się. „Ale jest to jednocześnie prawo mojego życia w tym sensie, że to, co wydarzyło się w moim życiu, najwyraźniej jest zgodne z krzyżem, którego nie dostrzegłem (nie zauważyłem tego faktu), zaszło zgodnie $\mathrm{z}$ tą sytuacją, a nie według mentalnych obrazów, idei, w tym

\footnotetext{
${ }^{41}$ Marcel Proust, A la recherche du temps perdu, T. 1-3 (Paris: Gallimard, 1954), 188. Mamardašvili, Lekcii o Pruste, 110.

${ }^{42}$ Mamardašvili, Psihologičeskaâ topologiâ puti, 349.

${ }^{43}$ Mamardašvili, Opyt fizičeskoj metafiziki, 21.

${ }^{44}$ Mamardašvili, Lekcii o Pruste, 30.

${ }^{45}$ Tamże, 287.
} 
idei miłości, braterstwa, które nagminnie mnożą się w mojej głowie"46. Pojęcie wysiłku to jedno z głównych pojęć służących do wyjaśniania tego, co i jak dzieje się z nami w prawdziwym życiu. Świat jest urządzony w taki sposób, że najistotniejsze spotykające nas wydarzenia, np. prawo albo bezprawie itd., zależą od wysiłków dokonywanych przez każdego człowieka. Wysiłek oznacza, że czegoś nie ma, dopóki nie zostanie podjęty trud. Całość świata Prousta płynie na szczycie fali intensywnych starań. Różnica pomiędzy ludźmi dotycząca tego, kto jest równy albo nie, będzie w głównej mierze określona faktem, kto podjął pewien trud, a kto nie ${ }^{47}$.

Mamardaszwili uznaje wysiłek za pojęcie egzystencjalne bądź kognitywne, które może podlegać jedynie intensyfikacji ${ }^{48}$. Może się ona w człowieku utrzymywać i trwać, lecz nie może być podtrzymywana za pomocą żadnego autonomicznego mechanizmu. Jeśli podejmujemy wysiłek, możemy go przedłużyć i ja jego sprawą budować wartości. „Prawda, piękno, cnota istnieją dlatego, że stale się ożywiają i odnawiają, stają się wciąż przekształcanym wysiłkiem. Trwanie pewnych rzeczy jest istnieniem, utrzymującym się na grzbiecie fali wysiłku. Fala wysiłku niesie istnienie czegoś w czasie i w trwaniu, ale my, będąc ograniczonymi istotami psychicznymi, widzimy trwanie, lecz nie dostrzegamy podpierającej go fali”" ${ }^{2}$. Właśnie dlatego zjawiska istotne dla człowieka mogą opierać się na rzeczach niemożliwych. „Niemożliwe nie jest tym, co jest możliwe beze mnie, niemożliwe jest tym, co jest utrzymywane moją własną wiarą i tylko dzięki niej” ${ }^{50}$. Pojęcie wysiłku pozwala uniknąć pomieszania dobrych spraw z dobrymi zamiarami. „Przecież świat urządzony jest tak, że dobro w nim istniejące nie jest naszym pragnieniem dobra" ${ }^{\prime 1}$. Moralne czyny i moralne wydarzenia wymagają o wiele większego wysiłku niż nasz zamiar bycia moralnymi. „W rzeczywistości zachodzą jedynie ontologicznie uzasadnione wydarzenia, a nie uczucia-skłonności półstworzeńn ${ }^{\prime 52}$. Mamardaszwili wykorzystuje metaforę „mięśni moralnych”: dziecko nie może pod-

\footnotetext{
${ }^{46}$ Mamardašvili, Psihologičeskaâ topologiâ puti, 251.

47 Tamże, 235-236.

${ }^{48}$ Mamardašvili, Lekcii o Pruste, 30.

49 Tamże, 318.

${ }^{50}$ Mamardašvili, Psihologičeskaâ topologiâ puti, 400.

51 Tamże, 238.

52 Tamże, 348.
} 
nieść się z krzesła, nie mając wystarczająco rozwiniętych mięśni. Specjalny rodzaj „mięśni” jest konieczny, by „podnieść" myśl, „podnieść” czyn moralny. „Tylko za pomocą mięśni w świecie coś zachodzi” ${ }^{33}$.

\section{Stracony i odzyskany czas}

Czas jest tym, czym przedmiot różni się od samego siebie, a przestrzeń tym, czym różni się on od innego przedmiotu ${ }^{54}$. Odnosi się to również do mnie samego, albowiem istnieje ogromna przepaść między mną a mną, gdyż wypełniony jestem nieodwracalnymi ruchami w świecie. Powinniśmy przechodzić od „ja” do „ja” ${ }^{55}$. Centrum psychologicznej topologii drogi stanowi teraźniejszość, która jest specyficznie interpretowana jako punkt stworzenia świata „tu i teraz”. „W życiu nie zawsze panuje tylko teraźniejszość. Najtrudniejsze wydaje się życie w teraźniejszości" ${ }^{\text {56 }}$. Nie mamy jasno określonych pojęć przeszłości, teraźniejszości i przyszłości, zaznacza Mamardaszwili ${ }^{57}$, dlatego że naszą obecnością bądź nieobecnością możemy zmieniać ich ramy, przykładowo: rozciągać teraźniejszość jako zanikający mały punkt przejścia z przeszłości w przyszłość. Jeżeli nie ma obecności, jeżeli nie lokuję samego siebie w tym procesie, wówczas nie mogę niczego odebrać i nie mogę niczego sobie przypomnieć. Jest to czas stracony. Czas gubi się tam, gdzie nie dokładamy starań, nie podejmujemy ryzyka i bierzemy odpowiedzialności za to, żeby być żywymi istotami. „Czas stracony jest porą wszystkich martwych chwil. Oznacza to, że czas zachodzi wtedy, kiedy mogłeś żyć w pierwszym tego słowa znaczeniu, jak już powiedziałem, lecz nie żyłeś. Był to dla ciebie znak, ale ty go przegapiłeś. Przegapiłeś, ponieważ nie zatrzymałeś się i nie działałes'"58. Wszystko, co jest prawdziwe i wartościowe, tj. rzeczywiste, trwa zawsze krótko. Powstaje luka w codziennym przepływie wydarzeń - jeszcze

\footnotetext{
${ }^{53}$ Tamże, 531.

${ }^{54}$ Mamardašvili, Lekcii o Pruste, 233.

${ }^{55}$ Mamardašvili, Psihologičeskaâ topologiâ puti, 218-219.

${ }^{56}$ Mamardašvili, Lekcii o Pruste, 204.

57 Tamże, 234.

${ }^{58}$ Mamardašvili, Psihologičeskaâ topologiâ puti, 52.
} 
sekunda i szczelina się zamknie, świat popłynie dalej w swoim kierunku, a na razie luka ta występuje, zaznacza Proust, zmieniając trochę sformułowanie z Ewangelii: „Pracujcie, dopóki światło jest z wami” ${ }^{2}$. Nie istnieje prawda uniwersalna, twierdzi Mamardaszwili, i nie ma prawdy na jutro. W każdym punkcie czasu może być ona wyłowiona tylko z jednego punktu. Dlatego nie należy zwlekać, nie można odkładać wszystkiego na potem. To, co rzeczywiście powinno się wydarzyć „tu i teraz”, nie może się zdarzyć kiedy indziej. Postrzeganie rzeczywistości (nie pozorów, nie iluzji) wymaga pełnej obecności ${ }^{60}$. Oznacza to bycie żywym, w pełni uczuć, chociaż nie możemy doświadczać pełni uczuć bez przerwy. Powinniśmy starać się jednak być w tym stanie tak długo, jak to możliwe. Świat prawdziwie otwiera się za sprawą doznawania. Niezbędna jest nasza pełna obecność, wtedy wrażenie przenika nas i otwiera nam drogę do samych siebie. Ale trzeba zdążyć doświadczyć tego wrażenia [doznania]. Zdążyłeś, jeżeli świat naturalnych powiązań nie stanął w miejscu tych wrażeń, nie zastąpił sobą tego doznania. Jeśli staramy się żyć realnie, nie możemy opierać się na przeszłości, ponieważ prawda, piękno, dobro istnieją dlatego, że w każdej chwili wymagają trochę wysiłku. Nie można opierać się na pewnych minionych zasługach, na przeszłych wydarzeniach. „Istnienie pewnych rzeczy jest istnieniem utrzymującym się na grzbiecie fali wysiłku”61. A to, co Proust nazywa przeszłością, to „pewien rezerwuar, który nabity jest nieprzypadkowymi przeżyciami”, tj. tymi, które mogłyby stać się przeżyciami, ale nie zostały stworzone i zrozumiane ${ }^{62}$. Momentem kluczowym jest uchwycenie sensu trwających wydarzeń. Od tego, czy się tak stanie, zależy to, jak potoczy się życie. Proust rozróżnia dwa rodzaje przeszłości.

Pierwsza $z$ nich to przeszłość, która się nie odbyła [jeszcze nie jest spełniona]. Ja ją dookreślam i uzupełniam - podkreśla Mamardaszwili. Dla przykładu: ukrzyżowanie Chrystusa nigdy nie jest ukończone. Żeby stało się ono dla ciebie realnością, powinieneś wziąć w tym udział, jakimś sposobem dokończyć to wydarzenie i uczynić go elementem swojego życia. Przeszłość jest czymś, co powinienem pomóc rozstrzygnąć. Mamardaszwili wykorzystuje w tym wypadku czasownik „odroczyć w czasie” [vremenit']. Czekać ozna-

\footnotetext{
${ }^{59}$ Mamardašvili, Lekcii o Pruste, 43.

${ }^{60}$ Tamże, 359.

${ }^{61}$ Tamże, 318.

${ }^{62}$ Tamże, 321.
} 
cza: nie pozwalać na jakieś pospieszne działanie. Człowiek ma tendencję, aby pojawiający się w nim stan zakończyć jakimś działaniem. Istnieją jednak stany niemożliwe do zakończenia. Przykładowo taki jest stan cierpienia, gdyż cierpiącemu nie można pomóc. Zazwyczaj mówimy: czas uleczy rany. Ale sam czas nie jest w stanie tego zrobić. Czas może pomóc tylko w przypadku, gdy człowiek znajduje się wewnątrz cierpienia i w żaden sposób nie można go skompensować bądź uśmierzyć lub w jakikolwiek inny sposób rozwiązać tego problemu. Jest to czasowość. „Wszystko, co nie jest czasowe, zostanie zapomniane. To, co będzie rozstrzygnięte $\mathrm{w}$ taki sposób, to przeszłość, która czekała, kiedy spieszyliśmy się, aby cokolwiek z nią zrobić"63. Bezczynność jest przeciwieństwem reaktywnego uwikłania człowieka w splot przyczyny i działania. Jeżeli opuściłem ten krąg przyczynowo-skutkowy, zatrzymałem się wewnątrz wydarzenia, wewnątrz trwającego czasu i niczego z nim nie zrobiłem. Znajduję się w nim, jestem tu obecny, przeżywam go, w takim razie mogę ten stan, działanie, przeżycie zakończyć, dookreślić.

Druga przeszłość jest tą, na którą się nie czeka, na którą się po prostu reaguje z przyczynowo-skutkowej konieczności. Jest to czas stracony. Nie wyciągnięto z niego sensu i nie opracowano jako struktury. Dlatego będzie się wciąż powtarzać, odtwarzać w kółko - taki obieg czasu w symbolice religijnej zestawiano z piekłem ${ }^{64}$. W piekle można bez końca powtarzać ten sam czyn, np. w nieskończoność żuć jeden kawałek mięsa, nie przeżuwszy go nigdy do końca. Piekło to zapomnienie, a coś raz zapomniane będzie się stale powtarzać. Jeżeli walczący naród nie zdobywa doświadczenia na wojnie, będzie ona powtarzać się nieustannie. Następuje zła nieskończoność powtórzeń: zgrzeszyć i pożałować, znowu zgrzeszyć i znowu pożałować, i tak bez końca. To właśnie niezdobyte doświadczenie skazuje na powtarzanie. Nic nie uległo zmianie. Oznacza to, że wydarzenie nie zaszło, więc nie może ono zostać uznane za przeszłe. W przeszłości czy w 1937 roku doszło do tego zdarzenia czy nie? Nie, odpowiada Mamardaszwili, nie wydarzyło się. Nie jest wyciągana $\mathrm{z}$ tego lekcja, która krystalizowałaby się w strukturach uniemożliwiających powtarzanie tego doświadczenia. Skrucha nie pomaga uciec od złego powtórzenia, jeśli „coś zostało usunięte ze struktury, a nie utrwaliło się w strukturze

\footnotetext{
${ }^{63}$ Mamardašvili, Psihologičeskaâ topologiâ puti, 145-158.

${ }^{64}$ Tamże, s. 138.
} 
osobowości”"65. W tym przypadku możliwe jest, aby powtórzyć tysiąc razy to samo i nie zauważyć, że nic się nie zmieniło. Czas, na który oczekiwaliśmy, był zanadto zakorzeniony w przeszłości, może być zapomniany, ale ma szansę na przywrócenie pamięci, mimowolne wyłonienie się właśnie dlatego, że nad nim pracowaliśmy. A to, na co nie zaczekaliśmy, znajdzie się poza bytem. Potrzebne jest oderwanie, odsunięcie się od samych siebie, ponieważ bezczynność tworzy lukę pomiędzy przeszłością a teraźniejszością, pomiędzy jedną przeszłością a inną, jest to jedyny sposób, dzięki któremu można się o sobie i o innych ludziach czegokolwiek dowiedzieć. Pojęcie przeżywania doświadczenia nawiązuje do idei Rollo Maya o pauzie pomiędzy bodźcem a reakcją jako zbiorniku ludzkiej wolności ${ }^{66}$. Kiedy robimy pauzę, przerywamy asocjacyjny związek między bodźcem a reakcją i stajemy się wolni, nie jesteśmy już częścią nieskończonego łańcucha naturalnej przyczynowości. Bez uświadomienia sobie sytuacji nie jesteśmy w stanie zrobić pauzy i odzyskać wolności. W duchu tym Mamardaszwili tłumaczy zagadkę Hamleta. Dlaczego Hamlet się waha? Myśliciel powołuje się na antyczne pojęcie koła losu, gdzie wszystko jest ze sobą połączone, wszystko wywołuje skutki i jest ze sobą powiązane. Sposób działania został przewidziany jako „kompot” z naturalnych przyczynowych łańcuchów - przestępczości i odwetu, zostawiający Hamletowi tylko jedną drogę. Hamlet był jednak bohaterem. „Bohater to ktoś, kto nie dokonuje działania zapisanego już przez sprzężenie łańcuchów przyczynowych, ale podejmuje działanie, za którym stoi on sam. Nie pasuje mu takie automatyczne wykonywanie zapisanego losu. Pragnie on zrozumieć sens" ${ }^{\text {67. Robiąc }}$ pauzę, rozmyślając, szuka wyjścia z sytuacji. Tylko odmawiając podążania za naturalnymi wydarzeniami, Hamlet może wyciągnąć z nich ukryty sens. Wystawiona przez niego sztuka służy jako narzędzie takiego wyciągania sensu, jest „maszyną przeżycia”. Tę jego pozycję Mamardaszwili za starogreckimi autorami nazywa amehaniey (zdolność dojrzałego powstrzymywania się od ruchu, od reagowania na wydarzenia). Hamlet przebywa w amehanii, nie reagując na wydarzenia, gdyż ważne jest dla niego przede wszystkim poleganie na wewnętrznym dążeniu do znalezienia sensu. Nie udaje mu się odnaleźć

\footnotetext{
65 Tamże, 74.

${ }^{66}$ Rollo May, Freedom and Destiny (New York: W. W. Norton \& Co., 1981).

${ }^{67}$ Mamardašvili, Lekcii o Pruste, 330.
} 
rzeczywistego wyjścia, ale cała historia Hamleta to dzieje człowieka posiadającego godność i zdolność uświadomienia sobie sytuacji, rozumiejącego jej strukturę, stojącego przed wyzwaniem koła losu i próbującego odnaleźć rozwiązanie. Dokładnie tego dokonuje w tragedii, próbuje, choć bezskutecznie, unikać z góry określonych wydarzeń, lecz ta walka, która zakończyła się klęską, czyni go bohaterem ${ }^{68}$. Czas rzeczywisty obejmuje proces zdobywania doświadczenia, czas ten może być skompresowany bądź rozciągnięty, zastąpiony innym albo przekształcony. Innymi słowy, „czas jest przedziałem między tym, co jest, a tym, co jest wywnioskowane i uznane” ${ }^{69}$. „Wydarzenie faktu znajduje się u kresu psychicznego badania, którego przestrzeń oddziela nas od bezpośredniego, natychmiastowego postrzegania faktów"70. Dlatego jedynie w momencie, gdy następuje zdobywanie doświadczenia, rozwijam się, zmieniam i posuwam naprzód. „Droga jest tym, co sprawia, że nie podwajamy czasu"71. Czas, który mnie indywidualizuje, to mój unikatowy czas, jest mi potrzebny, by poznać siebie. I jeśli komuś się to uda, uda mu się również poznać świat. Zdobywanie zaś doświadczenia niewątpliwie wymaga podjęcia trudu albo włożenia w to pracy. Stracony jest zwłaszcza ten czas, którego nie wykorzystaliśmy ${ }^{72}$. „[Ludzie] są synami natury, są synami światła. Syn natury to ten, kto żyje w trybie złych powtórzeń, nadziei, podwajającej świat i nigdy nieuznającej, że świat jest jeden, hic et nunc, wszystko dzieje się »tu i teraz«. Skoro nie zdobył doświadczenia teraz, to już nigdy go nie odzyska. I są synami światła albo synami pracy, pracy pogłębienia"73.

Mamardaszwili często cytuje słowa Prousta, które stają się faktycznie filozoficznym wyrazem jego stanowiska: „Życie to wysiłek w czasie" ${ }^{\text {. }}$. W innym miejscu Mamardaszwili bezpośrednio utożsamia czas i wysiłek, twierdząc, że to jedno i to samo ${ }^{75}$. Jest jeszcze jedno kluczowe metafizyczne twierdzenie, które Mamardaszwili odnajduje w powieści Prousta: „Świat w rzeczywisto-

\footnotetext{
${ }^{68}$ Mamardašvili, „Vvedenie v filosofiû (Fenomenologiâ filosofii)”, Novyj krug, no 2, (1992): 59. Mamardašvili, Psihologičeskaâ topologiâ puti, 156-157.

${ }^{69}$ Mamardašvili, Lekcii o Pruste, 453.

70 Tamże, 459.

71 Tamże, 34.

72 Tamże, 359.

${ }^{73}$ Tamże, 424.

${ }^{74}$ Mamardašvili, Psihologičeskaâ topologiâ puti, 7.

${ }^{75}$ Mamardašvili, Soznanie i civilizaciâ: Teksty i besedy, 83.
} 
ści nie został stworzony raz, by istnieć i trwać. Świat w rzeczywistości ciągle się tworzy"76. Nasze działania dokonują się stale w tworzącym się świecie, a nie w takim, w którym ludzie i rzeczy po prostu przebywają, trwają. „Bo za każdym razem sporo działo się w świecie, jesteśmy w przepływie, ale nie na początku"77. Świat nie może być postrzegany jako coś, co się stało, jako „gotowe”, byłby to świat, w którym jest już „za późno" ${ }^{\text {. }}$. Dlatego też, kiedy mamy do czynienia $z$ wartościami, nie możemy polegać na tym, co było. Przecież nic, w istocie, jeszcze nie zostało ustalone: „spoczywać w cnocie, szczęściu i świecie albo zbawić swoją duszę, to się nie uda. Żyć można tylko wewnątrz rodzącego się w tobie innego, kontynuującego w tobie swoje życie, jeżeli inny jest żywy, to żywy jesteś również ty"79. Dokładnie tak, że nie możemy niczego przesunąć w przyszłość. Istnieję tylko „tu i teraz”, jednak to „tu i teraz” holograficznie zawiera cały świat. Całe dzieło Prousta mówi nam o tym, że można wziąć dowolny mały kawałek życia ludzkiego i dostrzec w nim całe życie ludzkości we wszystkich jego splotach, co oczywiście odpowiada zasadzie „wiecznej teraźniejszości”. Po pierwsze, „wieczna teraźniejszość” istnieje w dowolnym mgnieniu i w każdym kawałku życia ludzkiego, oddzielnej jednostce bądź klasie jednostek. Po drugie, w „wiecznej teraźniejszości” dane są sploty wszystkich relacji, które w ogóle istnieją"

Jeden „aksjomat”, jak go nazywa Mamardaszwili, ujawnia wiele aspektów problemu czasu, ilustrując jednocześnie ideę prawa: „Ludziom często zdarza się działać, kiedy jest już za późno. W odniesieniu do tych sytuacji człowiek ma tylko jedną wolność, wolność znajomości prawa i wolność niestawiania siebie w takich sytuacjach, gdy jest już za późno" ${ }^{\prime 1}$. Mamardaszwili ilustruje typowy dla czasów radzieckich przykład: grupa artystów otrzymała zezwolenie na gościnne występy zagraniczne. Do ich powrotu przedstawiciel ambasady zabrał im na rzecz państwa znaczną część honorariów. Dlaczego jednak nikt nie protestuje? Wyjaśnienie tego w kategoriach cech osobowości, konformizmu bądź strachu byłoby błędne. „Prawo mówi co innego. Prawo

\footnotetext{
${ }^{76}$ Mamardašvili, Lekcii o Pruste, 81.

77 Tamże, 306.

78 Tamże, 305.

${ }^{79}$ Mamardašvili, Psihologičeskaâ topologiâ puti, 389.

80 Tamże, 394.

${ }^{81}$ Mamardašvili, Lekcii o Pruste, 71.
} 
mówi: jest już za późno. Dlatego, że postawiłeś siebie w takich warunkach, jesteś już łamistrajkiem, a nikt nigdy nie widział, żeby łamistrajkowie strajkowali. Dotyczy to twojego współdziałania z władzą i zależności od pieniędzy. Opiera się to na uprzywilejowanym wyróżnieniu cię z masy ludzi... My, żyjący na terytorium, zwanym Rosją, posiadamy fantastyczny talent zapędzania siebie w sytuacje, "gdy już jest za późno«"82.

\section{Osobowość jako możliwość i jako punkt tworzenia}

Jedno z kluczowych założeń antropologii filozoficznej gruzińskiego myśliciela głosi, że człowiek nie jest istotą naturalną, lecz sztuczną. „Ludzie nie rodzą się w sposób biologiczny, a tylko przechodząc przez tę drogę, stają się bądź nie stają ludźmi”" ${ }^{3}$. Idea osobistego ocalenia dzięki indywidualnej drodze stanowiła, według Mamardaszwilego, początkową formę myśli filozoficznej. „Życie nasze w dzisiejszym społeczeństwie kształtuje przecież naszą próbę, aby wyrwać się z tego, co nie należy do nas, aby skupić się na sobie. Jest próbą rozpoczęcia życia, które można byłoby rozpoczynać od samego siebie" ${ }^{\prime 4}$. Codzienny wir wydarzeń jest przypadkowy i absurdalny, nie mniej przypadkowe jest jednak miejsce i czas naszego pojawienia się na tym świecie. Aczkolwiek jeśli nie chcemy tkwić w tym cyklu, w tym „kole odradzania”, musimy odnaleźć drogę osobistego zbawienia i podążać nią ${ }^{85}$. Droga ta wymaga wysiłku i dzięki niej stajemy się ludźmi: „człowiek musi zdobyć się na trud, by być człowiekiem" ${ }^{\prime 6}$. Wynik ten nie jest zagwarantowany, zależy on jednak od naszych wysiłków. Posuwamy się ku człowieczeństwu w tej mierze, w jakiej jesteśmy zdolni i pragniemy podjąć trud, żeby stać się ludźmi. „Nigdy nie stajemy się ludźmi abstrakcyjnie, lecz stajemy się nimi, ponieważ potrafimy nimi być" ${ }^{\prime 7}$.

\footnotetext{
${ }^{82}$ Tamże.

${ }^{83}$ Tamże, 26.

${ }^{84}$ Mamardašvili, Opyt fizičeskoj metafiziki, 10.

${ }^{85}$ Tamże, 11-12.

${ }^{86}$ Mamardašvili, Psihologičeskaâ topologiâ puti, 119.

${ }^{87}$ Mamardašvili, Lekcii o Pruste, 502.
} 
Wielokrotnie Mamardaszwili próbuje scharakteryzować ten typ człowieka, który uważa za filozoficzny ideał. Mówił o „wewnętrznym człowieku” lub „człowieku Ewangelii” (w przeciwieństwie do „człowieka Kościoła”) ${ }^{88}$, o „uniwersalnym człowieku”, „bohaterskim człowieku” albo o „klasycznej duszy”. Jest to typ człowieka, który utrzymuje świat bez względu na normy i zaszłe przyczyny, stwarza prawa i normy na podstawie własnego doświadczenia wyniesionego z życiowej próby. „A próba ta jest ryzykowna, jesteś sam na sam ze światem [...] Poprzez własne ryzyko i strach przechodzisz przez tę drogę próby, a próba ta ma nieskończoną wartość"89. Konstruktywną rolę lęku i strachu Mamardaszwili opisuje praktycznie w taki sam sposób, jak analizowali ją Kierkegaard, Tillich, May, Maddi i inni egzystencjaliści ${ }^{90}$. To, co nosi nazwę lęku, jest wyraźną świadomością odpowiedzialności za swoje przeznaczanie. Twoja autentyczna droga, twoje autentyczne życie rozwinie się, jeżeli pójdziesz drogą tobie przeznaczoną. Lecz na tej drodze nie ma żadnego oparcia. Jest to przerażające ${ }^{91}$. Klasyczna dusza nie potrzebuje pomocy z zewnątrz, cokolwiek by się wokół niej działo, może działać, gdyż włada nią „męstwo niemożliwego”. Nie istnieją żadne mechanizmy, które niezależnie od twojego wysiłku i twojego męstwa mają coś światu do zaoferowania ${ }^{92}$. Mamardaszwili przeciwstawia sobie dwa kluczowe obrazy: rewolucjonisty i bohatera. Każda ideologia rewolucyjna opiera się na idei determinizmu środowiskowego: należy zmienić warunki tak, żeby wszyscy stali się lepsi. Człowiek nie może stać się lepszy w pojedynkę. Tradycja bohaterska dotyczy tego samego, co tradycja metafizyczna, i oznacza podążanie za tym, jak świat działa. Ludzie zasadniczo mają zdolność do zachowania moralnego, nie szukając przy tym przyczyn i sensu, by być dobrymi i równocześnie czynić dobro. „Ja sam, jeden na jednego w obliczu świata muszę radzić sobie z własną samotnością. Jakikolwiek by był ten świat, jest coś, co mogę i powinienem zrobić"93. Rewolucjonista wierzy, że jednego wspaniałego dnia wszyscy razem staną się lepsi. Bohater gotowy

\footnotetext{
${ }^{88}$ Tamże, 104.

${ }^{89}$ Tamże.

${ }^{90}$ May, The Meaning of Anxiety (New York: W. W. Norton \& Co., 1977).

${ }^{91}$ Mamardašvili, Psihologičeskâ̂ topologiâ puti, 179.

92 Tamże, 108.

${ }_{93}$ Tamże, 197.
} 
jest do zmiany samego siebie, cokolwiek robiliby inni. „Klasyczna dusza jest duszą męską, zdolną do tego, by stawić światu czoła, bez względu na to, jak dużo byłoby w nim nieszczęść, rozkładu, chaosu, nierówności, niesprawiedliwości. Zdolna jest do tego, aby nie zwracać uwagi na fakty dotyczące niesprawiedliwości, nierówności albo nieszczęścia, by nie zwracać na nie uwagi, jak na alibi, które pozwala samemu niczego nie robić, nie mieć żadnego zamiaru. Klasyczna dusza zdolna jest, mimo wszystko, do przyjęcia określonego, skończonego, wewnętrznego kształtu, tak że źródła szczęścia albo nieszczęścia przesuwają się w samą formę życia albo twórczości, którą dany człowiek albo dana dusza włada" ${ }^{4}$. Jest to droga ciernista, droga największego wysiłku i oporu, a także „tytanicznej walki z Bogiem” ${ }^{95}$. Sztuka bohaterska bądź bohaterska świadomość to świadomość pracy wolności i odpowiedzialności. Potworny ciężar, który człowiek przy każdej sposobności chce z siebie zrzucić, to brzemię pracy i wolności ${ }^{96}$. Innymi metaforami opisującymi ten typ osobowości są „,człowiek wertykalny”, „człowiek wartościowy” oraz „człowiek spójny”97. Idea konstruowania siebie jako pewnej osobowości dojrzałej i dorosłej stała się jedną z kluczowych podczas drugiego kursu wykładów o Prouście. W pojęcie konstruowania wpisuje się sens zarówno dobierania „cząstek żywego doświadczenia”, jak i ich tworzenia w przemyślaną strukturę, przy czym osobowość występuje jako „punkt konstrukcji”. „Jestem tutaj, w tym punkcie, »tu i teraz « muszę połączyć się z samym sobą. Łączę się z samym sobą, opracowując albo przerabiając wrażenia"98. Jedynym autorem, oprócz Mamardaszwilego, u którego uobecnia się podobna idea tworzenia, jest Carl Gustav Jung. W jego teorii rozwoju osobowości ludzie najpierw projektują swoje nierozpoznane i niepożądane cechy na świat zewnętrzny i innych ludzi, a następnie, wraz z dalszym rozwojem, zaczynają zbierać te projekcje i integrować je na powrót ze swoją osobowością. Interesujące jest, że Jung, jak również Mamardaszwili, mówił o takich cechach dojrzałej, rozwiniętej osobowości jak własna unikatowa droga, własne wewnętrzne prawo i właściwe niedająca się usunąć samot-

\footnotetext{
${ }^{94}$ Tamże, 212.

95 Tamże, 336.

${ }^{96}$ Tamże, 206.

97 Tamże, 146.

${ }^{98}$ Tamże, 151.
} 
ność ${ }^{99}$. Oprócz mięśni psychicznych, odwagi znoszenia samotności, braku wsparcia i wskazówek właściwe bohaterskiej duszy jest to, co Mamardaszwili nazywa świadomością dorosłą. Z jednej strony taka świadomość łączy się z przekonaniem, że świat jest neutralny w odniesieniu do nas: „dorosłe spojrzenie, wymagające męstwa duszy, jest uznaniem faktu, że w świecie rzeczy dzieją się samoistnie. W stosunku do nas nie mają one charakteru intencji. A intencje, które u nich funkcjonują, są jedynie tym, co im przypisaliśmy”"100. Takie spojrzenie „wymaga męstwa, odwagi, dyscypliny, czyli wyznaczenia granicy"101. Przeciwnie, infantylna świadomość oparta jest na domniemaniu, „że wszystko w świecie dzieje się dlatego, żeby nas cieszyć, albo dlatego, żeby nas martwić"102. Z drugiej strony świadomość dorosła jest związana z przeświadczeniem, że nie jesteśmy obojętni w tym sensie, że jesteśmy odpowiedzialni za realizację naszych zamierzeń. „Słowa typu: »nie chciałem «, »byłem tak dobrze nastawiony«, »ukierunkowany« są zakazanymi kategoriami. Zakazane są dla rozwoju świadomości bohaterskiej. Jeżeli rozwinęliśmy się, nie możemy myśleć w taki sposób, żeby można było następnie powiedzieć, że nie dotyczyło to naszych intencji. Oznacza to przede wszystkim, że po prostu nie myślałeś. Nie dlatego, że nie chciałeś, lecz w momencie ostatniej godziny nie myślałes'”103. Podsumowując, Mamardaszwili pisze: „Żyć w rzeczywistym życiu to żyć w świecie, w którym nie ma sprawców twoich nieszczęść i nie ma nagrody za jakieś twoje zalety i zasługi" 104 .

Z rozumienia osobowości Mamardaszwilego jako punktów integrujących wynika, że pojęcie osobowości charakteryzuje się nie tyle czymś faktycznym, ile czymś możliwym. „Struktura osobowości jest w rzeczywistości strukturą możliwego człowieka, nie tego człowieka, którym jest, i nie strukturą abstrakcyjnej logicznej możliwości, lecz strukturą potencjalnego człowieka. Powiedziałbym, że struktura osobowości jest jakby obliczem głębokiej pustki, nie

\footnotetext{
${ }^{99}$ Carl Gustav Jung, Struktura psihiki i process individuacii (Moskva: Nauka, 1996).

${ }^{100}$ Mamardašvili, Psihologičeskaâ topologiâ puti, 65.

101 Tamże, 460.

102 Tamże, 64-65.

103 Tamże, 206-207.

104 Tamże, 483.
} 
ma tam niczego, jest tam pusto, a możliwy człowiek również jest pustką"105. Z tego powodu świadomość jest możliwością świadomości, a myśl jest możliwością myśli ${ }^{106}$. Właśnie dlatego zachowanie osobowościowe nie ma przyczyn. „Zrobić coś osobiście, właśnie osobiście (nie dlatego, że należysz do partii, do narodu, nie dlatego, że jesteś dobry lub zły - właśnie bez powodu). Można też podjąć działanie, podstawą którego jest sama osobowość albo jakaś zabawa, specjalnie pozostawiona przez pustą przestrzeń możliwego człowieka"107.

\section{Ciąg dalszy}

W naszych czasach ludzkość zmaga się z wieloma problemami i kryzysami. Rozmaite hierarchie społeczne, wartości przez wieki wydawały się naturalne i niezachwiane. W XX stuleciu przekonanie to jednak runęło, a antyczna idea równości odrodziła się w postaci doktryny praw człowieka. Doktryna ta z kolei stała się źródłem nowych problemów. Nawet najbardziej rozwinięte społeczeństwa pozbawione są teraz pewności co do swojej przyszłości. W dominujących naukach społecznych i politycznych brakuje wysiłku i odpowiedzialności. Zdaje się, że ludzkość zapomniała o nierozerwalnym związku między prawami z jednej strony a obowiązkami, odpowiedzialnością, kompetencją i zaangażowaniem z drugiej. Zerwanie tego związku niesie ze sobą negatywne konsekwencje nie tylko dla społecznej sprawiedliwości, ale również dla antropologii filozoficznej i teorii osoby. „Prawa posiada tylko ten, kto włada sobą"108. Ćwierć wieku temu Mamardaszwili postawił naszej cywilizacji diagnozę katastrofy antropologicznej, grożącej zniszczeniem podstaw ludzkiej egzystencji ${ }^{109}$. Wskazywał kierunek, w którym należy podążać, by odnaleźć wyjście: droga do możliwego człowieka, stale przekraczającego siebie i zdolnego do wysiłku w celu dokonania przemiany. „Wolny jest tylko

\footnotetext{
105 Tamże, 413.

106 Tamże, 334.

107 Tamże, 426.

108 Tamże, 193.

109 Tamże, 9.
} 
ten człowiek, który jest gotowy i posiada rzeczywistą siłę do pracy ku wolności" ${ }^{110}$. Iosif Brodski mówił, że chociaż tego świata nie da się już uratować, to poszczególnego człowieka można uratować zawsze. Mamardaszwili wskazał drogę do tego, czym jest jasna świadomość, precyzyjne myślenie, męstwo i wysiłek. To ciężka praca, lecz nie ma dla niej alternatywy. Z głównymi wyzwaniami XXI stulecia zderzamy się przecież „na polu odpowiedzialnego działania, gdzie do człowieka wracają następstwa jego czynów"111.

Przekład i opracowanie Aleksandra Kondrat Uniwersytet Mikołaja Kopernika, Toruń, Polska ORCID: 0000-0003-3879-4099 e-mail:moskwa.ros@gmail.com

\section{Bibliografia}

Bugental James. 1991. "Lessons Clients Teach Therapists". Journal of Humanistic Psychology, vol. 31, 3 .

Bugental James. 1991. "Outcomes of an Existential Humanistic Psychotherapy: A Tribute to Rollo May", The Humanistic Psychologist, 19, 1.

Mamardašvili Merab. 1995. Lekcii o Pruste (psihologičeskaâ topologiâ puti). Moskva: Ad Marginem.

Mamardašvili Merab. 2009. Opyt fizičeskoj metafiziki (Vil’nûsskie lekcii po social’noj filosofii). Moskva: Progress-Tradiciâ.

Mamardašvili Merab. 1997. Psihologičeskaâ topologiâ puti. Moskva: Izdatel'stvo Russkogo Hristianskogo gumanitarnogo instituta.

Mamardašvili Merab. 2004. Soznanie i civilizaciâ: Teksty i besedy. Moskva: Izdatel'stvo „Logos”.

Mamardašvili Merab. 1992. „Vvedenie v filosofiû (Fenomenologiâ filosofii)”, Novyj krug, no 2.

May Rollo. 1981. Freedom and Destiny, New York: W. W. Norton \& Co.

May Rollo. 1977. The Meaning of Anxiety. New York: W. W. Norton \& Co.

\footnotetext{
110 Tamże, 94.

111 Tamże, 93
} 
Motrošílova Nélli Vasílevna. 2007. Merab Mamardašvili: filosofskie razmyšleniâ i ličnostnyj opyt. Moskva: Progress-Tradiciâ.

Proust Marcel. 1954. A la recherche du temps perdu. T. 1-3. Paris: Gallimard.

Solov'ev Ėrih Ûr'evič. 2009. „Ėkzistencial’naâ soteriologiâ Meraba Mamardašvili”. In:

Merab Konstantinovič Mamardašvili, edited by Nélli Vasílevna Motrošílova. Moskva: ROSSPÈN.

Jung Carl Gustav. 1996. Struktura psihiki i process individuacii. Moskva: Nauka.

\section{Abstract \\ Merab Mamardashvili’s Philosophy of Life and Its Implications for Psychology}

The article presents important aspects of Merab Mamardashvili's philosophy of life, which is based on his lectures from the 1980s. The text presents the similarities and differences of Mamardashvili's thought regarding existential tradition in philosophy and psychology, and their significance for personality psychology. It seems important to distinguish between two modes of life: conscious and automatic. The key issue is time, gaining experience from various events, and integrating personality. In Mamardashvili's philosophy, a new dimension of personality, which was not expressed in the 20th century psychological theories of personality, is revealed. This dimension is associated with a conscious level of existence that goes beyond the causal patterns of biological and social human functioning.

Keywords: existentialism; psychology, consciousness; causality; personality.

\section{Streszczenie}

\section{Filozofia życia Meraba Mamardaszwilego i jej znaczenie dla psychologii}

Artykuł prezentuje ważne aspekty filozofii życia Meraba Mamardaszwilego na podstawie jego wykładów $z$ lat 80 . W tekście przedstawiono zarówno podobieństwa, jak i różnice idei Mamardaszwilego dotyczące tradycji egzystencjalnej w filozofii i psychologii oraz ich znaczenie dla psychologii osobowości. Istotne wydaje się rozróżnienie dwóch trybów życia (świadomego i automatycznego). Kluczowy jest również problem czasu, zdobywania doświadczenia z rozmaitych wydarzeń i scalania 
osobowości. W filozofii Mamardaszwilego ujawnia się nowy wymiar osobowości, który nie został wyrażony w psychologicznych teoriach osobowości XX stulecia. Wymiar ten wiąże się ze świadomym poziomem egzystencji wykraczającym poza przyczynowe schematy biologicznego i społecznego funkcjonowania człowieka.

Słowa kluczowe: egzystencjalizm; psychologia, świadomość; przyczynowość; osobowość. 